Jesús Alejandro Rodríguez Ayllón

jarodrigue1@uma.es http://orcid.org/0000-0003-4325-3705 Universidad de Málaga

(Recibido: 27 may 2021/ Received: 27th May 2021) (Aceptado: 9 julio 2021 / Accepted: 9 th July 2021)

\section{LA LITERATURA INFANTIL EN EL UNIVERSO ARTÍSTICO DE JOSÉ MORENO VILLA'}

\author{
CHILDREN'S LITERATURE IN THE ARTISTIC UNIVERSE \\ OF JOSÉ MORENO VILLA
}

\title{
Resumen
}

Se acaban de cumplir 75 años de la publicación, en 1945, de la antología Lo que sabía mi loro, libro en el que José Moreno Villa trata de ofrecer una amplia colección de los textos literarios que marcaron su infancia. Ese mismo año colabora en la edición de Navidad, villancicos, pastorelas, posadas, piñatas, publicado por Manuel Altolaguirre. En ambas obras destaca la mano de José Moreno Villa como poeta, antólogo e ilustrador. El presente estudio, además de examinar su faceta de ilustrador, trata de analizar con detenimiento las producciones incluidas en estos libros para evidenciar el deseo de Moreno Villa de ofrecer a los posibles lectores infantiles un panorama exhaustivo y profundo de la literatura española. Todas estas facetas revelan la conexión de la producción de Moreno Villa con el público infantil al que iban dirigidas estas dos obras.

Palabras clave: José Moreno Villa; Literatura española; Literatura infantil; Ilustración; Antología de poesía.

\begin{abstract}
It has been 75 years since Lo que sabia mi loro by José Moreno Villa was published. In that anthology the author tried to offer a wide collection of literary texts that marked his childhood. As well in the same year, 1945, he collaborated in the Navidad, villancicos, pastorelas, posadas, piñatas, published by Manuel Altolaguirre. The influence of José Moreno Villa as a poet, anthologist and illustrator is remarkable in both works. Apart from examining Moreno's illustrator skills, the present study deeply analyzes these books productions, demonstrating his desire to offer child readers an exhaustive and deep insight of the Spanish literature. All these facets reveal the connection of Moreno's production with the children's audience to whom these two works were targeted.
\end{abstract}

Keywords: José Moreno Villa; Spanish literature; Children's Literature; Illustration; Poetry anthology.

1 Expresamos aqui nuestro efusivo agradecimiento a don José Moreno Nieto. Muy amablemente nos ha facilitado la reproducción de las imágenes realizadas por su padre que acompañan y enriquecen el texto de este artículo. 


\section{Moreno Villa: un escritor múltiple y versátil}

José Moreno Villa (Málaga, 1887 - Ciudad de México, 1955) es sin duda una de las personalidades más interesantes y complejas de la cultura española de la primera mitad del siglo XX. Su obra intelectual es tan extensa y heterogénea que incluye todas las artes: poeta, traductor, dramaturgo, crítico literario, historiador y crítico de arte, dibujante, pintor, ilustrador, ensayista y narrador, figura fundamental en la cultura española de su tiempo, se le ha designado a menudo como un humanista del siglo XX².

De todo ese complejo y productivo mundo intelectual, una de las facetas menos conocidas y reconocidas quizá sea su interés por la literatura infantil, interés que se materializó en dos obras coetáneas publicadas en 1945: Lo que sabía mi loro y Navidad, villancicos, pastorelas, posadas, piñatas. Y aunque se trata de dos obras diferentes entre sí, debe destacarse en ellas la presencia de Moreno Villa como ilustrador y como poeta. El interés y la consideración de Moreno Villa por la poesía infantil eclosionan precisamente en ese año de 1945 por unas circunstancias vitales muy determinadas.

En febrero de 1937 Moreno Villa es enviado por el gobierno de la República a Estados Unidos, país donde dicta varias conferencias y recibe diversas ofertas académicas. En ese momento, crucial en su vida, Estados Unidos parece su destino de acogida. Sin embargo, en su camino se cruza Genaro Estrada, embajador de México en España durante los primeros años de la República, el cual lo invita a viajar a México, adonde llega en mayo de 1937. Según Sánchez Ortiz (2013:377) la elección de México entre muchos de los intelectuales exiliados no fue casual, pues este pais contaba entonces con un presidente de la República cuyo proyecto educativo era muy similar al de la malograda Institución Libre de Enseñanza. La posterior muerte de su amigo y protector lo empujan a casarse en enero de 1939 con la viuda de este, Consuelo Nieto. En 1941 nacerá su hijo José, cuando el poeta cuenta con cincuenta y cuatro años de edad. Sin duda el nacimiento de este hijo está en la génesis de Lo que sabía mi loro. Esta primera obra de creación motivará su posterior participación en Navidad, villancicos, pastorelas, posadas, piñatas.

Se ha repetido a menudo que la obra de Moreno Villa está necesitada de revisión y examen ${ }^{3}$, necesidad que surge por la parcial o escasa atención por parte de la crítica hacia su obra, atención que se ha limitado a aspectos muy concretos de su producción poética, narrativa y autobiográfica ${ }^{4}$. Queda pendiente, entre otras facetas, la vertiente de Moreno Villa como recuperador, creador y editor de poesia infantil.

Entre los múltiples intereses intelectuales de Moreno Villa podria destacarse su atención hacia la lírica popular, interés que entronca con la tendencia natural que los poetas del 27 desarrollaron de recuperación y revalorización del patrimonio literario español. Sin embargo, resulta interesante

2 Romero Tobar (1989: 92) nos recuerda cómo Guillermo de Torre se ha referido a él como el "Leonardo malagueño".

3 Carnero (1989: 13) comenzaba su ponencia en el I Congreso de Literatura Española Contemporánea con estas palabras: "José Moreno Villa es uno de los muchos escritores españoles de este siglo necesitados de revisión y examen, y no solo por lo que en ello pueda haber de reparación moral póstuma, sino porque en un exacto conocimiento de la aportación de quienes, como él, tuvieron la mala suerte de venir al mundo literario entre dos épocas bien definidas y dotadas de figuras de primera magnitud reside la única posibilidad de entender orgánicamente y sin transiciones bruscas la historia literaria de los decenios segundo y tercero de nuestro siglo XX"

4 En 1987 se celebró en Málaga el I Congreso de Literatura Española Contemporánea con el título José Moreno Villa en el contexto del 27. En 1989 se publicaron las actas bajo la dirección del profesor Cristóbal Cuevas (Cuevas y Montesa, 1989), donde es analizada la obra literaria de José Moreno Villa desde distintos ámbitos. En ninguno de los ensayos se afronta el estudio de la relación de Moreno Villa con la literatura infantil. 
apuntar que este interés en Moreno Villa es muy anterior al de los poetas del 27. Chica (2002) nos recuerda que en sus primeros libros de poemas (Garba, El pasajero, Luchas de "Pena" y "Alegría" y su transfiguración) nuestro autor ya había destacado en ese interés por la tradición clásica española:

Obras estas en la que la herencia modernista se pone al servicio de una voz que alterna los grandes temas del 98 con los registros de la poesía popular, captada en su lado más hondo y desde perspectivas innovadoras que adelantan en parte el mundo de la generación posterior. (...) Lo que se abre paso en estos libros es un impulso lírico que preludia (...) el horizonte de la nueva poesía, cargada en su caso por componentes rítmicos que, procedentes de la tradición andaluza, serán reaprovechados después en la obra de Lorca y Alberti. (604)

Se puede concluir, por tanto, que no se debe considerar a José Moreno Villa un escritor de literatura infantil en el sentido moderno, pues su producción literaria se muestra ante nosotros mucho más amplia y heterogénea. Pero si unimos la fascinación por la tradición lírica española, manifestada prontamente en su producción poética, con la motivación puramente personal, biográfica, se comprenderá perfectamente el puntual interés de nuestro autor hacia la lírica infantil, que eclosiona y se plasma en estas dos obras de 1945.

El universo infantil es un mundo en construcción. $Y$ en este mundo por construir juega un papel relevante la materia poética. La poesía infantil es un recurso extraordinario para el acercamiento de los niños al universo literario, en el que el desarrollo del hábito lector viene de la mano de obras que conecten con los intereses e inquietudes de los futuros lectores. Por eso las primeras lecturas que se ofrecen al niño lector tienen que estar próximas a sus intereses y capacidades, de manera que estas colaboren en la formación de su competencia lectora.

El escaso desarrollo de la poesía infantil en la España del primer tercio del siglo XX provoca que sea la poesía popular la base para el aprendizaje de la materia poética. No podía ser de otra manera pues no existe todavía nuestro concepto moderno de poesía infantil. Sabemos además que la lírica popular infantil es portadora de unos recursos físicos que facilitan la atracción por parte del público receptor. Las rimas, las repeticiones, los juegos de palabras, los sinsentidos, los trabalenguas (y un largo etcétera) atraen con su sonoridad al lector incipiente que es el niño. Además, van moldeando su propio concepto de literatura, sin olvidar que esta aproximación al hecho literario debe hacerse desde textos que estén en consonancia con sus intereses y sus expectativas.

Esta es la finalidad de los textos de Moreno Villa: ofrecer a sus posibles lectores un universo de producciones literarias heterogéneo y diverso que empatice con el lector infantil. Pero, al mismo tiempo, en estos textos queda reflejada una parte de su infancia, por lo que deben servir de salvaguarda de toda una tradición literaria que Moreno Villa siente ahora como lejana y mira con añoranza desde su exilio mexicano. 


\section{Lo que sabía mi loro. Una colección folclórica infantil reunida e ilustrada por José Moreno Villa}

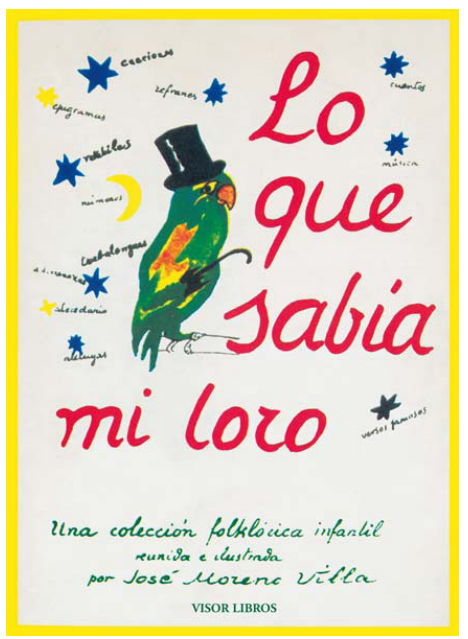

Ilustración 1. Portada de Lo que sabía mi loro (Visor Libros, 2011)

La primera edición de este libro vio la luz en 1945 y, como ha señalado Alatorre (2011: 3), estamos ante un libro autobiográfico en el que nuestro autor metió su infancia: todo aquello que Moreno Villa escuchó y vivió durante su niñez malagueña se plasma en este libro tan personal y brillante, y en él quiso dejar una impronta de lo que había sido, literariamente, su niñez. Se trata de un libro confeccionado, redactado e ilustrado para los niños.

El primer rasgo de su heterogeneidad viene marcado por su contenido. No podía ser de otro modo, ya que la materia de la que se ocupa Moreno Villa busca recuperar los propios recuerdos y vivencias infantiles, con lo que es la memoria (ese instrumento tan selectivo) el aparejo del que se sirve nuestro poeta para llevar a cabo su colección. Es en la selección de su contenido como Moreno Villa trata de recuperar y mantener vivo un legado cultural propio, nacido en España, que quiere transmitir a las nuevas generaciones mexicanas.

A modo de guardas el libro incluye distintas ilustraciones del propio autor (son reconocibles distintos animales y personajes de cuentos y fábulas, don Quijote, un busto de Cervantes...) que nos dan idea del contenido diverso, múltiple del libro. Y este contenido se abre hacia dos vertientes: los versos y narraciones compuestas por Moreno Villa, y los versos y narraciones recogidas e incluidas por el autor.

El libro arranca con dos creaciones del autor: un juego poético para aprender los números («Una, dos, ¿quién tiene tos?») y justo a continuación un original abecedario en el que cada letra se vincula con una imagen visual personalísima: "La A es como un naipe doblado y atravesado por una estilográfica. También como una escalera». "Cuando veas una D te acordarás del hombre panzón y de la barca de vela». Estas creaciones vienen acompañadas de unos geniales y originales dibujos del propio autor, que conforman casi unos auténticos ideogramas. (Ilustraciones 2 y 3 ) 


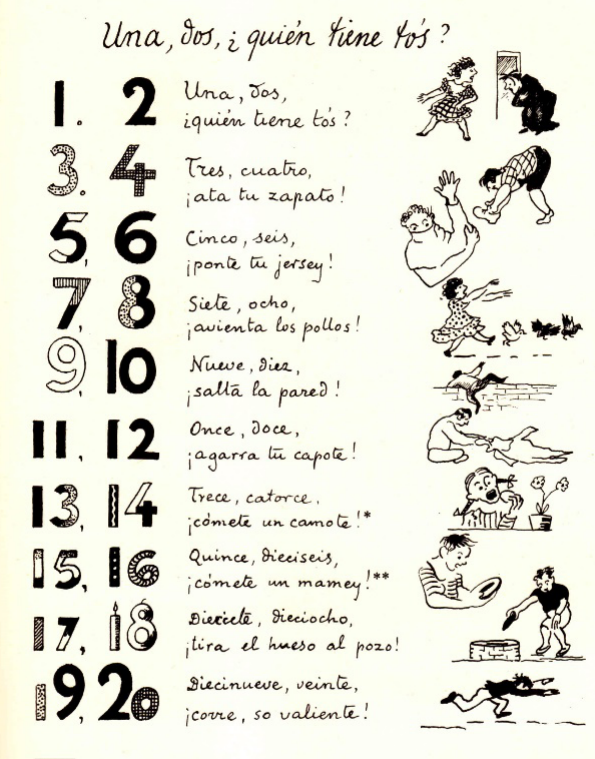

\section{:}

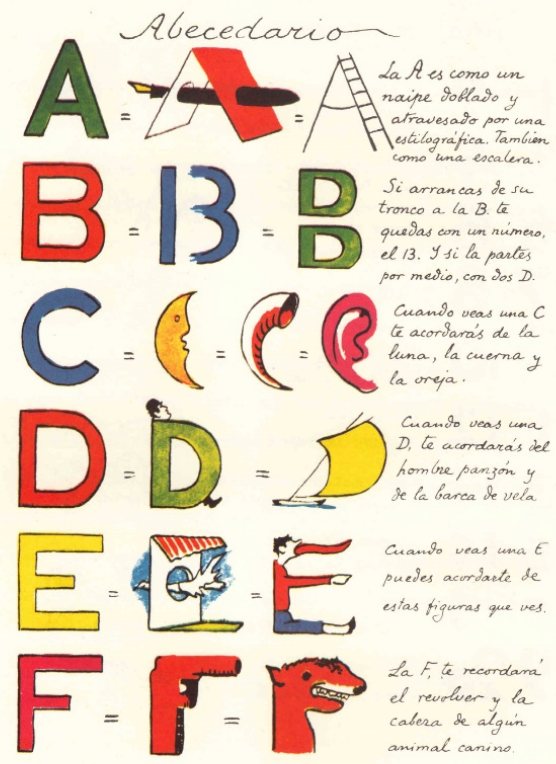

Ilustración 3. Abecedario

Entre las creaciones propias de Moreno Villa se incluye también una colección de trece pareados que tratan de aspectos diversos del circo y del mundo circense que van acompañando a las ilustraciones (ilustración 4): "Cualquiera que al circo va / con los clons se reirá»; "Las más simpáticas damas / saltan grandes oriflamas».

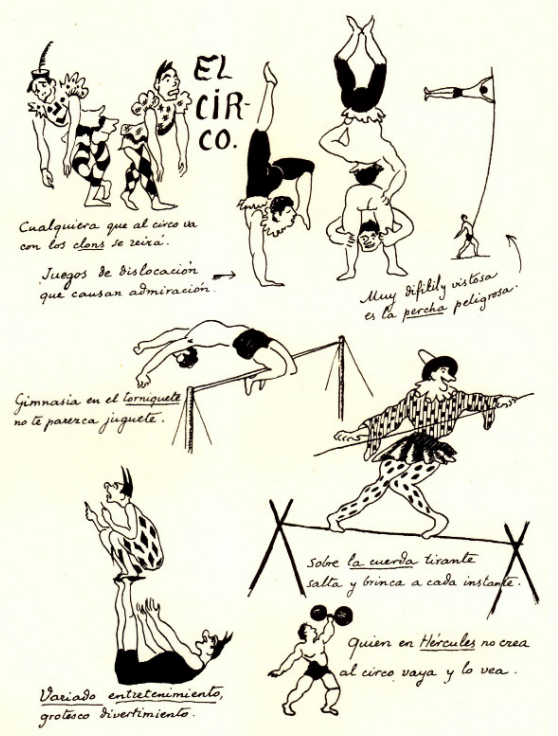

Ilustración 4. El circo 
A continuación, nos encontraremos con un universo heterogéneo de textos, en los que Moreno Villa dirige su interés y atención hacia un extenso mundo literario. El editor selecciona poemas de autores clásicos españoles e hispanoamericanos ya que considera de vital importancia preservar y difundir los grandes textos de la tradición lírica a la que pertenece. La selección incluye «Volverán las oscuras golondrinas» de Bécquer, "Qué descansada vida» de fray Luis de León, "No salgas, paloma, al campo» en la versión de García Lorca, "La princesa está triste» y "Juventud, divino tesoro» de Rubén Dario, "Para y óyeme, joh Sol! yo te saludo" de Espronceda, "Escribidme una carta, señor cura» de Campoamor, "Admirose un portugués» de Nicolás Fernández de Moratín, "La rosa blanca» y "Yo pienso, cuando me alegro» de José Martí.

Los fragmentos de prosa los conforman un resumen del Quijote seguido de la versión personal de Moreno Villa de las aventuras de don Quijote con los rebaños y con los molinos, y dos capitulos de Platero y yo de Juan Ramón Jiménez: "La púa» y "Pasan los patos». La finalidad de estos textos es la misma que poseen los textos líricos: preservar y difundir una concreta tradición literaria, y, al mismo tiempo, contribuir al desarrollo de la competencia literaria de los futuros lectores, con textos diversos y de naturaleza múltiple.

Sin embargo, en el ámbito de la literatura popular es donde la colección de textos se vuelve más ambiciosa, pues nuestro autor pretende ofrecer un repertorio amplio y variado que incluya el máximo número de manifestaciones literarias populares diferentes. Un recorrido por el contenido del libro nos da una idea del criterio de exhaustividad que persigue el autor.

Las formas en prosa están representadas por un cuento popular, «El borrico engañó al diablo cuando chico» ${ }^{5}$ y dos fábulas, "El cuervo y el zorro" y "La zorra y la rana». El cuento y la fábula forman parte de una tradición cultural que el lector incipiente puede comprender y hacer suya gracias a su estructura sencilla (planteamiento-desarrollo-desenlace). Esta estructura facilita su comprensión por parte del receptor, y facilita, también, unas herramientas esenciales sobre las convenciones de los textos literarios. Es una primera aproximación al mundo de la ficción por parte del niño-receptor, y es un eslabón importantísimo en su proceso lector.

Otros textos en prosa son los diálogos humorísticos «¿Qué es la patria?» y «Encontré un ratón». Ambos aparecen en la misma página bajo el epígrafe "Diálogos». Moreno Villa elabora dos textos sencillos y breves, cuya lectura nos revela su claro valor humoristico, con una estructura similar al chiste o al chascarrillo.

El cancionero tradicional, como conjunto de poemas anónimos de temática muy variada y de extensión breve, difundidos de forma oral, atrajo el interés de los poetas del 27 y, concretamente, de nuestro autor. Ya se ha apuntado más arriba cómo muy pronto Moreno Villa se había sentido interesado por la lírica popular española procedente del cancionero, hasta el punto de que puede rastrearse su influencia en sus primeros textos líricos. En la selección realizada por nuestro autor para Lo que sabía mi loro algunos títulos provienen de esta larga tradición popular como es el caso del villancico «De los álamos vengo, madre». Esta composición fue registrada por el compositor y músico renacentista Juan Vásquez en su Recopilación de sonetos y villancicos a cuatro y cinco voces (Sevilla, 1560). Desde ahi será ampliamente recogida y versionada.

Del cancionero tradicional también extrae Moreno Villa otra interesante y curiosa muestra: se trata de la seguidilla «El pelele está malo». El poema está conectado con la costumbre de mantear un

5 Se trata de un cuento popular de larga tradición que ya aparece en el romance "De la antigüedad y excelencias del borrico», impreso en Málaga en 1790, y recogido por Alvar (1974: 387-390). 
muñeco de paja, conocido como "el pelele", durante los días del carnaval, costumbre que tuvo enorme pujanza desde el siglo XVIII y que llega hasta el primer tercio del siglo XX, tal y como puede verse en Fraile Gil (2007).

Las muestras del refranero popular español también ocupan un espacio importante en Lo que sabía mi loro. Cantera (2012) define el refrán como «dicho sentencioso de uso bastante difundido y que se va transmitiendo de generación en generación». Y añade que algunos se distinguen por su aspecto bimembre y por una rima generalmente sencilla que facilita su memorización. Como cualquier otra manifestación de la cultura popular, el mundo del refrán es inmenso, y entre sus finalidades se ha señalado su afán por enseñar algo útil para la vida práctica, marcando pautas para el recto proceder 0 censurando otras veces vicios o la torpe manera de actuar o de comportarse; es decir, nos transmiten un acervo de saberes en los que se han ido plasmando formas muy diferentes de representar la realidad. Moreno Villa salpica las páginas de su libro con una variedad de refranes, a los que dedica tres páginas en total, como por ejemplo «El mal torero en la calle mucha planta, y en la plaza mucho miedo" o "Al más chico muerde el perro".

La adivinanza es una de las formas tradicionales de la poesía oral infantil enormemente extendida, una manifestación de la cultura popular de extremo interés por su amplia temática y sus recursos retóricos y estilísticos, en la que se mezclan lo lúdico y lo ingenioso, fácilmente memorizable gracias a su brevedad. Es, además, un género especialmente rico por la variedad de temas que se pueden tratar. Moreno Villa sabe valorar su potencialidad, por lo que ofrece en su libro un curioso conjunto de adivinanzas, cinco páginas en total, y de entre ellas sirva como ejemplo la dedicada al instrumento de peso tradicional, la romana: «En Roma me bauticé / y tengo por nombre Ana. / Ando quitando porfias / por todo el reino de España».

Los trabalenguas son un tipo de juego basado en la complicación sonora de las expresiones que los constituyen. Estas expresiones a menudo no tienen una base lógica, y es la materia física la que los dota de su gracia y chispa. Cerrillo (2003) se refiere a ellos como una especie de "burla»:

[...] ya que son cantinelas que un emisor propone a un destinatario para que las repita con exactitud, sabiendo de su dificultad y con la casi total certeza de que, al menos al principio, se equivocará, lo que provoca un momento de mofa o burla, por la torpeza expresiva de quien intenta el recitado. (90)

Recordemos, como nos indica este autor, que se usan en un contexto lúdico, algo consustancial a la poesía popular de tradición infantil. Los trabalenguas que Moreno Villa selecciona para su libro son "Maria Chucena», "La perra de Parra», "El perro Zaranguangüita» "En un triste plato de trigo»" "Esta era una madre que biraba, biraba», "¿Usted gusta...?» y "Paco Peco, chico rico», aunque este último lo incluye Moreno Villa dentro de una página dedicada a "poesías burlescas». Y este emplazamiento es lógico, si consideramos, como afirmaba Cerrillo, que el trabalenguas es una forma más de burla.

El palíndromo es, según el Diccionario de la Real Academia Española (DRAE), "palabra o frase cuyas letras están dispuestas de tal manera que resulta la misma leída de izquierda a derecha que de derecha a izquierdan. Se trata de un juego de palabras, ingenioso, aplicable no solo a la literatura sino a otros ámbitos como las matemáticas o la música. Su carácter formal atrae la atención del receptor, que se centra fundamentalmente en la forma del mensaje más que en su contenido. Moreno Villa las define como "frases de ida y vuelta "o que se leen lo mismo por la derecha que por la izquierda"» e incluye dos: "Anita la Valatina» y «Dábale arroz a la zorra el abad». 
Otra muestra importante de literatura popular recogida por nuestro autor en su libro son las Ilamadas aleluyas, también conocidas como aucas en catalán. Pelegrín (1986) nos facilita la siguiente definición:

Género de literatura popular difundida especialmente en el siglo XIX y principios del XX, circularon profusamente en las ventas callejeras de pliego de cordel, boticas y pequeños comercios donde acudian los niños para comprar manuales y abecedarios escolares. (149)

Nos encontramos ante poemas narrativos acompañados de imágenes (normalmente en un formato de cuarenta y ocho viñetas) que narran vidas de hombres célebres, novelas, obras teatrales en boga, aunque también existía un grupo de estas obras con temática puramente infantil como cuentos, mitología, abecedarios, barajas, loterías, vidas absurdas, animales pintados por sí mismo, juegos... La forma más común del pie rimado suele ser el pareado, como es el caso de las aleluyas de Moreno Villa, "Vida del hombre flaco ${ }^{6}$ " y "Corrida de toros». Estas dos aleluyas, sin embargo, no se atienen al formato tradicional de cuarenta y ocho viñetas, pues cada una de ellas consta solo de doce, seguramente por el deseo de Moreno Villa de ofrecer una muestra amplia y diversa de textos.

Entre los subgéneros líricos que atraen la atención de Moreno Villa se encuentra el epigrama. Recordemos que el epigrama, según el $D R A E$, es una "composición poética breve en que, con precisión y agudeza, se expresa un motivo por lo común festivo o satíricon. Se trata de un subgénero constante en la lírica española, que ha tomado multitud de formas y ha tratado de los más variados temas, pero que no se caracteriza, precisamente, por ser un género eminentemente infantil. De ahí que nos llame la atención la inclusión en el libro de los epigramas «El cura de Alcañiz» y «Bendito sea el gramófono». En esa misma página dedicada a los epigramas, Moreno Villa incluye la fábula de Samaniego «Dijo la zorra al busto", en la que sobresale el valor epigramático por encima del puramente fabulístico. También podrían incluirse en este apartado las composiciones "Doña Bárbara Braganza» y "Vuestro don, señor hidalgo", etiquetadas por nuestro autor como "poesías burlescas", y que comparten con los epigramas su valor mordaz, crítico y humorístico.

Un espacio importante en el libro lo ocupan los romances, una expresión literaria de tradición oral que forma un tronco fundamental de la literatura infantil. Pelegrín (1990) apunta la importancia que, a lo largo de los siglos, esta manifestación poética ha tenido en el universo literario del niño:

Tengo observado que, si bien en los juegos, especialmente de comba y de corro, es donde viven los romances, el niño, en la sociedad tradicional, gozaba de otros canales de transmisión. Aprendía romances en el hogar, en la plaza, en el aula, en las fiestas, en las reuniones vecinales, en los juegos. Formaba parte de una cultura oral. El niño accedia a la biblioteca oral en las distintas ediciones y versiones del romancero familiar, a la videoteca de los juegos jugados. (42)

Consciente de esta importancia, Moreno Villa incluye varias composiciones quizá usadas como canciones populares o para su recitación, pero cuya estructura métrica corresponde a la del romance, tales como «A la verde, verde» 0 "El gato y la gata».

6 Esta obra fue editada en forma de libro independiente por el Consejo Nacional para la Cultura y las Artes como lectura escolar en 1998 y con ilustraciones de Marcela Derbez (y con una segunda edición en 2001). Véase Cañamares et al. (2013: 155). 
Es en el apartado de canciones populares infantiles donde el repertorio ofrecido por Moreno Villa se vuelve más amplio y complejo, y a la vez más interesante, y donde se mezclan composiciones de muy diverso tipo.

Así, entre las composiciones extraídas del cancionero popular infantil Moreno Villa incluye un elenco muy variado, entre las que podemos localizar las que se dicen o se cantan con un apoyo gestual o escénico. Cerrillo (2005: 59) las denomina juegos mímicos y son interpretadas por el adulto con la intención de que el niño lo imite o lo acompañe. Entre estas se sitúan las que se ejecutan para contar con los dedos como es el caso de "Este puso un huevo.... incluida por Moreno Villa en su libro.

Sin embargo, el mayor número de composiciones corresponde a las canciones escenificadas, entre las que se incluyen retahílas de sorteo como "Cu-cú cantaba la rana»; retahila-escena de prendas como "Antón Perulero»; canciones de corro o rueda como "Yo soy la viudita»", "Mambrú se fue a la guerra» ${ }^{10}$, "San Serenín de la buena vida»" o "Tengo una muñeca»" ${ }^{12}$; canciones de invocación y conjuro como "Luna, lunera...."; r retahílas en forma de cuento sin final como "Las once y media serían»; canciones petitorias como "Que llueva, que llueva»14; o canciones acumulativas con una serie enumerativa como «Una hora duerme el gallo».

Por último, en el libro se incluyen dos canciones populares de tradición general, recogidas y musicadas por Federico García Lorca (de las que se nos ofrece, además, la partitura): "Los cuatro muleros" y "Los reyes de la baraja». No es una casualidad. La admiración de Moreno Villa (1976) por el Lorca músico era manifiesta, como él mismo así lo expresó en su autobiografía:

Federico era un alma musical de nacimiento, de raíz, de herencia milenaria. La llevaba en la sangre, como Juan Brevas, Chacón o la gran "Argentina". Daba la impresión de que manaba música, de que todo era música en su persona. Aqui radicaba su poder, su secreto fascinador. Despedía música y, donde él caía o entraba, caía o entraba el arrebato alegre y levitante de la música. (110)

Es muy importante no olvidar que todos estos textos vienen acompañados por las ilustraciones tan personales y características del autor que conforman ese universo propio de seres imaginarios e imaginados. No es un mérito más de la obra; al contrario, se convertirán en un valor que prolongará la vida de este texto en posteriores ediciones.

Como sabemos, a menudo las antologías revelan el gusto y los intereses del autor que las confecciona, se erigen en ventanas a través de las cuales sabemos más de quien las ha elaborado.

$7 \quad$ Así la clasifica Pelegrín (1986: 104).

8 Véase Beltrán et al. (2002: 23)

9 Se trata de una canción (para danza de ronda/rueda) infantil con múltiples variantes según la región donde se cante. La letra consta de entre tres y cinco estrofas, y suele cantarse a dos voces (viudita y corro). La versión de Moreno Villa consta de cuatro estrofas: dos para el recitado de la viudita y dos para el del corro.

10 Véase Cillán Cillán (2004).: Estudio literario de una canción de corro: Mambrú se fue a la guerra, Alcántara: revista del Seminario de Estudios Cacereños, 59-60, 2004, pp. 9-24.

11 "Las tonadas y canciones del Serenin fueron muy conocidas y populares; una pieza breve teatral de A. Zamora, Fin de fiesta del Serenin (1719), trae reflejada esa popularidad en siglos pasados», apud Beltrán et al. (2002: 51).

12 Véase J. M. Beltrán et al. (2002: 158)

13 De nuevo recurrimos a la clasificación de Pelegrín (1986: 89).

14 Véase Medina (1990: 50). 
Los textos contenidos en Lo que sabía mi loro se entienden mejor si consideramos las circunstancias vitales que habitan en el origen del libro. Moreno Villa trata de ofrecer una amplia muestra de un legado literario que, para él, corría peligro. El objetivo de su autor es mantener vivo ese legado y ofrecerlo a una nueva generación de lectores que, como su hijo José, estaban en riesgo de no conocer sus raíces culturales. Se nos invita a disfrutar de una variada muestra del folclore infantil, una personal combinación de textos y de géneros unidos en un libro singular.

Del interés del que la obra ha gozado nos dan idea las distintas ediciones que se han realizado desde su publicación inicial en 1945 en la editorial Isla, propiedad de Manuel Altolaguirre. En 1977 Alfaguara preparó una edición en la colección Infantil Juvenil Alfaguara con prólogo de Luis Izquierdo. En 1997 la editorial Compañia Literaria publicó una edición facsimilar donde se incluye el prólogo de Luis Izquierdo. En 2010 se publica en México por la editorial El Colegio de México, también en edición facsimilar. En 2011 de nuevo en edición facsimilar fue publicado por Visor Libros. Como se ve, después de unas décadas de olvido, la obra ha recuperado su interés y demuestra claramente su vigencia para los lectores actuales.

\section{Navidad, villancicos, pastorelas, posadas, piñatas (dibujos de José Moreno Villa)}

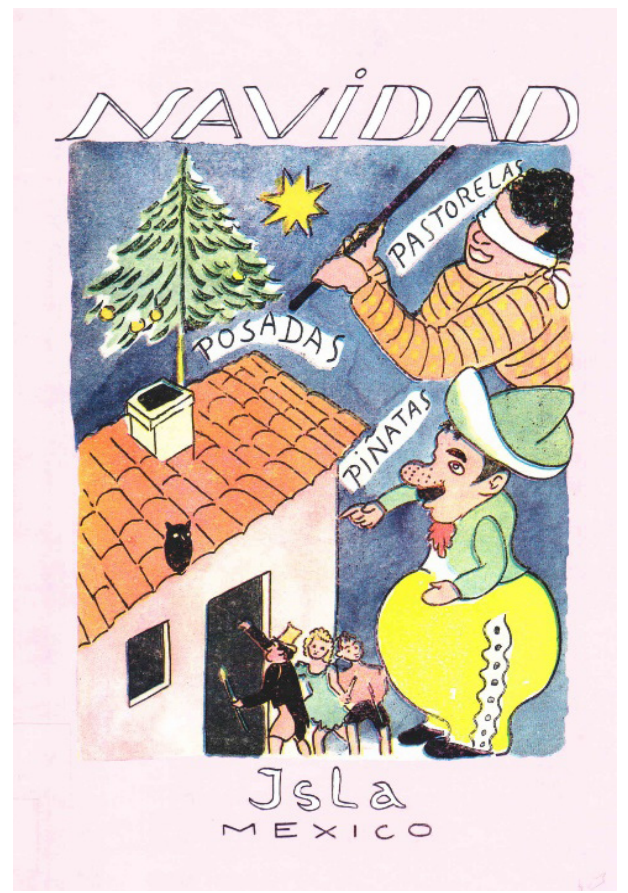

Ilustración 5. Navidad, villancicos, pastorelas, posadas, piñatas (Servicio de Publicaciones de la Universidad de Castilla-La Mancha, 2008)

En este segundo libro la presencia de Moreno Villa como poeta es mucho menor, no asi la de ilustrador, como veremos a continuación. Una certera contextualización del libro y de los textos contenidos en él nos la ofrece Gabriel Núñez en el estudio preliminar con el que se abre la edición facsímil publicada por el Servicio de Publicaciones de la Universidad de Castilla-La Mancha en 2008. 
Como en el anterior volumen, el libro se inicia, a modo de guardas, con una canción anónima acompañada de la partitura musical que funciona como aviso de lo que el lector encontrará en su interior.

Se trata de una recopilación de diversos poemas centrados en la Navidad ${ }^{15}$, que además se nutre de las propias producciones de Moreno Villa como ilustrador. Manuel Altolaguirre, responsable de la selección de los poemas y edición del libro, recoge una amplia muestra del folclore infantil navideño, con poemas de autores clásicos como Lope de Vega, Góngora y Alonso de Ledesma, de su esposa Concha Méndez, y villancicos populares. Se incluyen aqui también piezas típicas de la cultura mexicana, como las posadas, y se cierra con tres villancicos firmados por "El dibujante», es decir, Moreno Villa, dos de ellos para acompañar a una piñata.

La selección realizada por Altolaguirre está organizada en dos partes. En la primera se incluyen una pastorela anónima y once villancicos, de los cuales seis son populares y cinco de autor. En la segunda parte, "Versos para pedir y dar limosna". Altolaguirre selecciona una posada anónima de seis estrofas, con estructura dialogada, y una pastorela. En este apartado se incluyen los tres últimos poemas del libro, firmados por "El dibujante». La selección que elabora Altolaguirre, por tanto, se nutre de los villancicos populares españoles, por un lado, y por otro de manifestaciones del folclore mexicano.

Krutitskaya (2013: 267) explica que hoy en dia las posadas se celebran en México principalmente en el ámbito familiar o parroquial, y representan el peregrinaje de José y María desde su salida de Nazaret hasta Belén. En algunos lugares las posadas se realizan los nueve dias previos a la Navidad; en otros solo se organiza una posada, pero dentro de las fechas mencionadas. La tradición marca escrupulosamente las letanías, las oraciones y los versos que tendrán que ser recitados y cantados cada día de celebración del viaje. Más adelante esta autora (2013: 269) nos aclara que, cuando se trata de una celebración en el ámbito familiar, la piñata para los niños cobra una especial importancia junto al intercambio de regalos. $Y$ añade:

La práctica de las posadas navideñas se convierte en una vivencia profundamente infantil. (..) Probablemente la parte religiosa no les llame mucho la atención a los niños, pero sí todo aquello que tiene que ver con los juegos infantiles organizados por los adultos, la comida típica navideña, la piñata y, en algunos casos, la escenificación de la pedida de la posada. (269)

En este artículo la autora incluye, además, testimonios personales muy interesantes sobre el valor de estas celebraciones.

En el primer poema (ilustración 6) Moreno Villa se ocupa de la espera deseosa durante la noche de Reyes, la impaciencia y la ilusión propia de esa noche mágica. La métrica es sencilla, doce versos octosílabos con rima asonante en los versos pares. Además, está escrito en primera persona, por lo que parece tratarse de un recuerdo infantil.

15 En Cañamares et al. (2013: 151-152) se destaca la variedad de títulos dedicados a la Navidad entre la literatura infantil y juvenil creada por los exiliados españoles en México. 


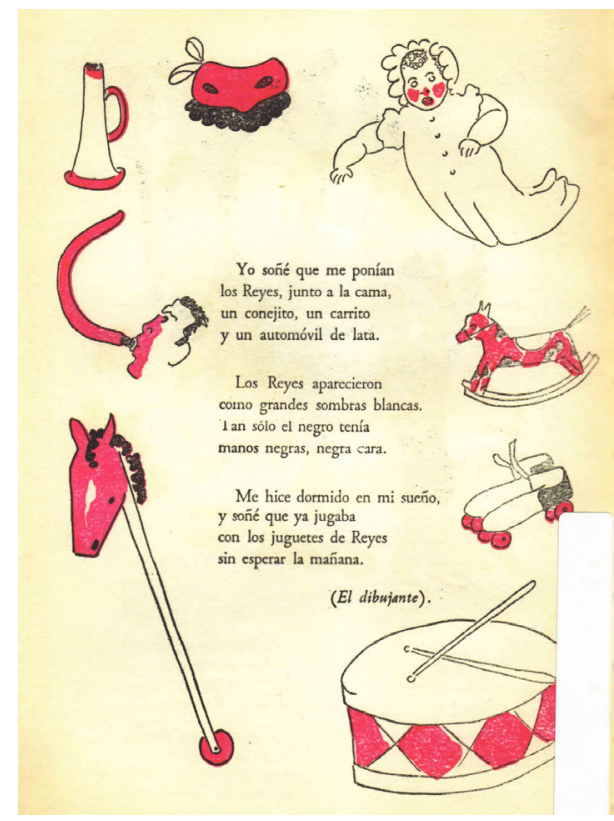

Ilustración 6. Yo soñé que me ponían...

La piñata se convierte en un momento de celebración infantil fundamental dentro de las posadas. Los niños se arremolinan debajo de la piñata esperando el momento en el que esta se abra. Los dos últimos poemas (ilustraciones 7 y 8) se estructuran en función de ese momento ${ }^{16}$. Se trata de una tradición muy difundida en México, con la que entroncarian los dos poemas compuestos por Moreno Villa.

16 De nuevo Krutitskaya (2013: 270) recoge diversos testimonios sobre jóvenes mexicanos que recuerdan esta celebración. En este estudio se recogen además diferentes canciones que se entonan en el momento cuando se rompe la piñata. 


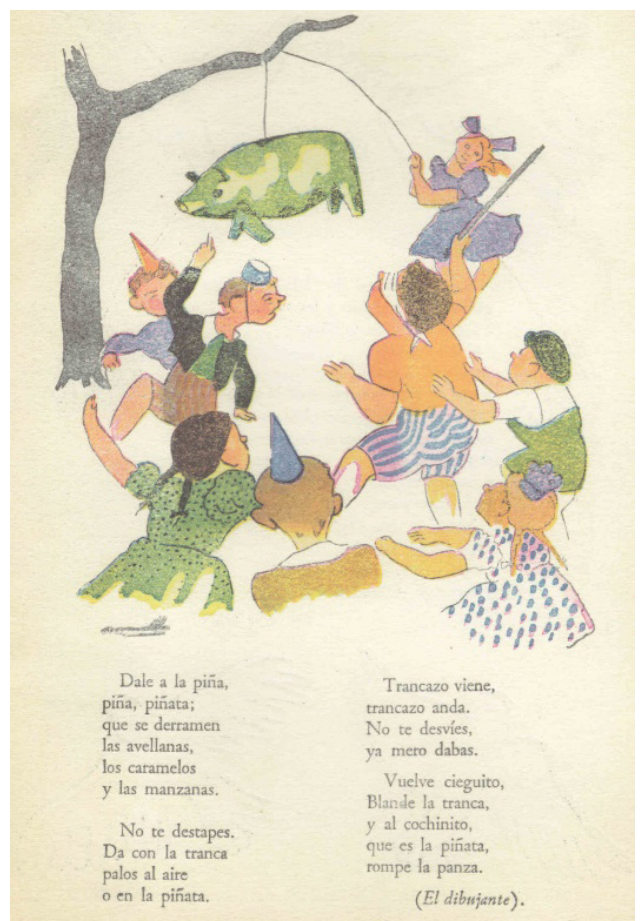

Ilustración 7. Dale a la piña...

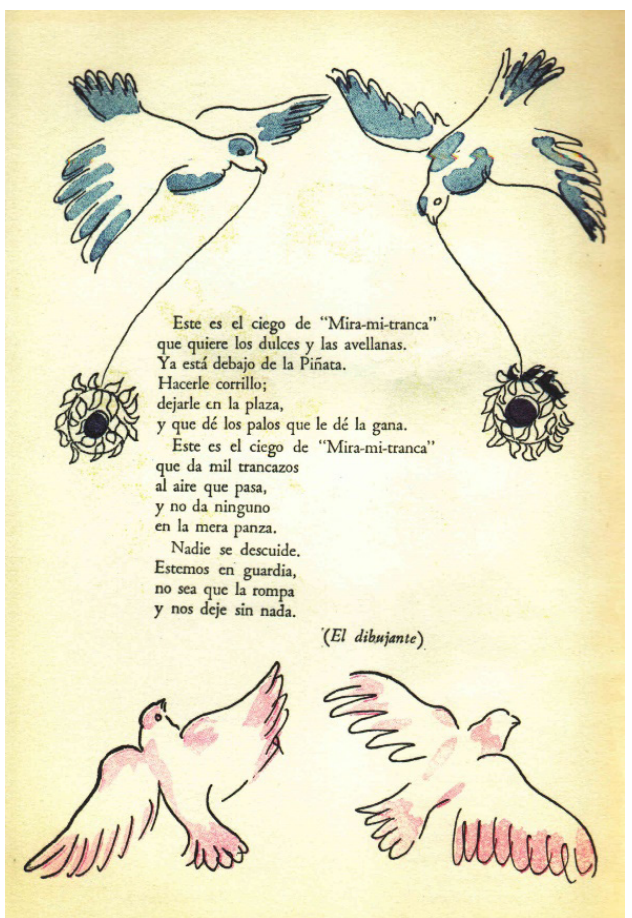

Ilustración 8. Este es el ciego de «Mira-mi-tranca»...

Los tres poemas de Moreno Villa pueden encuadrase perfectamente en la larga tradición de la lírica popular, cuya recuperación y puesta en valor, como se ha indicado más arriba, estaba entre los objetivos culturales de nuestro autor. Por su forma (versos cortos y sencillos, con rima asonante) tienen como objetivo ser fácilmente recitados y cantados. Sin embargo, mientras el poema «Yo soñé que me ponian» tiene un valor más lírico y personal, autobiográfico, claramente evocador, los poemas "Dale a la piña" y "Este es el ciego.... conectan directamente con las canciones y retahilas propias del juego de tradición oral, cuyas letras nos dan pistas para reconocer su ritmo y su compás.

El libro fue publicado por Manuel Altolaguirre en 1945. Al igual que ocurriera con Lo que sabía mi loro, el interés por esta obra es relativamente reciente. Así, existe una edición facsímil de 2008, con estudio preliminar de Gabriel Núñez, y publicada por el Servicio de Publicaciones de la Universidad de Castilla-La Mancha. Ese mismo año la editorial Visor realizó otra edición facsimilar. El Colegio de México publicó en 2013 una nueva edición facsimilar.

No se trata de dos libros legados al olvido. Sánchez Ortiz (2013: 379) los sitúa como dos de los tres libros más difundidos de lírica popular de tradición infantil editados en México en la segunda mitad del siglo XX, junto con la antología publicada por Mercedes Díaz Roig y María Teresa Miaja titulada Naranja dulce, limón partido.

Las recientes ediciones facsimilares nos dan idea de que cada uno de estos libros por sí mismos, como objeto, siguen suscitando interés. El criterio editor siempre ha sido el de ofrecer una edición facsimilar, sin duda para poder recoger y conservar los dibujos originales de Moreno Villa, una más de las múltiples riquezas que atesoran las dos obras. 


\section{Moreno Villa, ilustrador de poesía infantil}

El talento multidisciplinar de Moreno Villa tuvo también su reflejo en su interés por las artes plásticas en todas sus dimensiones. Pintor, dibujante, ilustrador, autor de retratos, historiador y crítico de arte, vivió siempre atento a las manifestaciones artísticas de su tiempo. Fue un firme impulsor de las vanguardias y supo adoptar los estilos pictóricos que predominaban en cada momento. Sobre su faceta artística, amplia y compleja, contamos entre las publicaciones más recientes con el estudio de González Presencio \&t García Alonso (2017), los cuales nos recuerdan el papel destacado de Moreno Villa dentro del panorama artístico y cultural de su época. Su obra artística se conserva, entre otros, en el Museo Reina Sofía de Madrid y en el remozado Museo de Málaga ${ }^{17}$.

Como sabemos, el lenguaje visual juega un papel esencial dentro de la literatura infantil. García Padrino (2004: 12) destaca cómo la «ilustración sirve, esencialmente, para despertar el interés de ese receptor, y, a la vez, para estimular y enriquecer su capacidad comprensiva en favor de un mejor y más completo acceso a la totalidad del mensaje contenido en una obra ilustradan. Lluch (2010: 109) afirma que "las imágenes convierten los libros en objetos artísticos: obras que se observan con detenimiento, que suscitan emociones, reflexiones, búsquedas interiores, formas de comunicar lo que en ellas se descubren.

De todas sus facetas artísticas es la de ilustrador la que más estrechamente une a Moreno Villa con la literatura infantil. Antes de enfrentarse a la elaboración de los títulos que nos ocupan, nuestro autor ya había afrontado la tarea de realizar las ilustraciones para varios libros en el ámbito de la literatura infantil. En 1935 asumió la tarea de ilustrar El carbón y la rosa, la obra de teatro infantil de Concha Méndez. Posteriormente, aunque no es posible precisar la fecha, para la editorial Cruz y Raya hizo lo propio con los cuentos de Giambattista Basile Las siete palomas y El archipámpano de las pulgas, traducidos por Rafael Sánchez Mazas.

Para Lo que sabía mi loro, su personal antología editada por Isla en 1945, Moreno Villa asumió no solo la selección de textos, sino que también los ilustró de manera profusa y confeccionó de su propia mano los textos que los acompañan. De esta manera Lo que sabía mi loro se nos presenta como un libro heterogéneo en sus textos, pero dotado de una peculiar unidad gracias a su contenido visual. La personal caligrafía de Moreno Villa inunda todo el libro y le otorga un carácter artístico irrenunciable.

En el siguiente libro, Navidad, villancicos, pastorelas, posadas, piñatas, la antología encargada por Manuel Altolaguirre y publicada también en 1945, Moreno Villa ocupa menos espacio como poeta para pasar a desempeñar fundamentalmente el papel de ilustrador. Su conocimiento del arte mexicano, con el que toma contacto a raíz de su exilio, marca poderosamente las ilustraciones de este libro. Cañamares et al. (2013) ponen de relieve la importancia de las ilustraciones en este volumen:

Con esa conciencia del mestizaje, de su importancia y su riqueza, el autor creó para ese libro ilustraciones de personajes mestizos junto a figuras de personajes españoles, una bella combinación que habla del sincretismo artístico que él supo encontrar y comprender (217).

Y Urdiales (2008) nos ofrece una esclarecedora sintesis del lenguaje visual del que se sirve Moreno Villa en sus ilustraciones:

17 Sobre el origen y vicisitudes de esta colección puede consultarse el artículo de López (2004). El autor de este estudio expresaba en su artículo un claro deseo sobre esta colección («esperamos verla pronto expuesta de nuevo en las salas de un renacido Museo de Málaga») por fin cumplido: el Museo de Málaga fue reubicado e inaugurado en 2016, y en él está expuesta la colección Moreno Villa. 
En las ilustraciones de ambos libros renuncia a sus recursos y conceptos pictóricos; el resultado es un dibujo muy sencillo, perfilado y con color plano, planteado con un toque humoristico y que muestra una exagerada torpeza, cualidad que en muchas ocasiones se fuerza para acercarse al mundo infantil; en estos dibujos no parece forzada, por el contrario resulta demasiado natural. (70)

Como conclusión se puede afirmar que, si bien José Moreno Villa destacó como artista polifacético y multidisciplinar, en su acercamiento a la literatura infantil supo dejar su impronta en dos obras fundamentales dentro del panorama de la literatura infantil española en el exilio.

\section{REFERENCIAS BIBLIOGRÁFICAS}

Alatorre, A. (2011). De folklore infantil. Boletín Editorial de El Colegio de México, 150, 3-13.

Alvar, M. (1974). Romances en pliego de cordel (siglo XVIII). Málaga: Ayuntamiento de Málaga.

Beltrán, J. M., Diaz, J., Pelegrín, A. Et Zamora, Á. (2002). Folklore musical infantil. Madrid: Ediciones Akal.

Cantera, J. (2012). Diccionario Akal del refranero español. Madrid: Ediciones Akal.

Cañamares, C., De Amo, J. M., Llorens, R., Luján, Á. L.; Guerrero L. González, C. \&t Sánchez, C. (2013). La literatura infantil y juvenil y los exiliados españoles en México. En Cerrillo, P. \& Miaja de la Peña. M. T. (Coords.). La literatura infantil y juvenil española en el exilio mexicano (pp. 75239). San Luis Potosi: El Colegio de San Luis; Cuenca: Ediciones de la Universidad de Castilla-La Mancha.

Carnero, G. (1989). José Moreno Villa y las orientaciones de la vanguardia española. En Cuevas García, C. \&t Montesa Peydró, S. (coordinadores) (1989). José Moreno Villa en el contexto del 27 (Actas del I Congreso de Literatura Española Contemporánea) (pp. 13-29). Barcelona: Anthropos.

Cerrillo Torremocha, P. C. (2003). Lírica popular de tradición infantil. Una propuesta de clasificación. En Cerrillo Torremocha, P. C. Et Yubero, S. (Coords.). La formación de mediadores para la promoción de la lectura. Contenidos de referencia del
Máster de Promoción de la Lectura y Literatura Infantil (pp. 81-94). Cuenca: Universidad de Castilla-La Mancha, Centro de Estudios de Promoción de la Lectura y Literatura Infantil, Junta de Comunidades de Castilla-La Mancha.

Cerrillo Torremocha, P. C. (2005). La voz de la memoria. Estudios sobre el cancionero popular infantil. Cuenca: Ediciones de la Universidad de Castilla-La Mancha.

Chica Hermoso, F. (2002). José Moreno Villa. En Cuevas Garcia, C. (Dir. y Ed.). Diccionario de escritores de Málaga y su provincia (pp. 602-61). Madrid: Castalia.

Cillán Cillán, F. (2004). Estudio literario de una canción de corro: Mambrú se fue a la guerra. Alcántara: revista del Seminario de Estudios Cacereños, 59-60, 9-24.

Cuevas García, C. \&t Montesa Peydró, S. (coordinadores). José Moreno Villa en el contexto del 27 (Actas del I Congreso de Literatura Española Contemporánea) (pp. 13-29). Barcelona: Anthropos.

Fraile Gil, J. M. (2007). Peleles y coplas del Carnaval madrileño, Revista de Dialectología y Tradiciones Populares, LXII (2), juliodiciembre 2007, 207-228.

García Padrino, J. (2004). Formas y colores: la ilustración infantil en España. Cuenca: Ediciones de la Universidad de Castilla-La Mancha.

González Presencio, M. \& García Alonso, M. (2017). El poeta Moreno Villa pintor. 
EGA: Revista de expresión gráfica arquitectónica, 22 (30), 214-221.

Krutitskaya, A. (2013). Las nueve jornadas de los santos peregrinos: usos y costumbres de tradición infantil. En Cerrillo Torremocha, P.C. \& Sánchez Ortiz, C. (Coords.). Presencia del cancionero popular infantil en la lírica hispánica (Homenaje a Margit Frenk) (pp. 265-284). Cuenca: Ediciones de la Universidad de Castilla-La Mancha.

Lluch, G. (con la colaboración de Fundalectura Colombia) (2010). Cómo seleccionar libros para niños y jóvenes. Los comités de valoración en las bibliotecas escolares y públicas. Somonte-Cenero, Gijón: Ediciones Trea.

López, R. V. (2004). La Colección Pictórica Moreno Villa del Museo de Málaga. Mus-A:Revista de los museos de Andalucía, 4, 112-121.

Medina, A. (1990). La tradición oral como vehículo literario infantil. Sus valores educativos. En Cerrillo Torremocha, P. C. Et García Padrino, J. (Coords.). Literatura infantil (37-65). Cuenca: Universidad de Castilla-La Mancha.

Moreno Villa, J. (1976). Vida en claro: autobiografía. Madrid: Fondo de Cultura Económica.
Pelegrín, A. (1986). Cada cual atienda su juego. De tradición oral y literatura. Madrid: Editorial Cincel.

Pelegrín, A. (1990). Poética y temas de la tradición oral (el romancero infantil). En Cerrillo Torremocha, P. C. Et Garcia Padrino, J. (Coords.). Poesía infantil. Teoría, crítica e investigación (pp. 37-49). Cuenca: Universidad de Castilla-La Mancha.

Romero Tobar, L. (1989). Moreno Villa, editor de clásicos y románticos. En Cuevas García, C. (Ed.). José Moreno Villa en el contexto del 27 (Actas del I Congreso de Literatura Española Contemporánea) (pp. 92-120.). Barcelona: Anthropos.

Sánchez Ortiz, C. (2013). Educación, cancionero y exilio: literatura infantil oral en la obra de José Moreno Villa. En Cerrillo Torremocha, P. C. Et Sánchez Ortiz, C. (Coords.). Presencia del cancionero popular infantil en la lírica hispánica (Homenaje a Margit Frenk) (pp. 373-383). Cuenca: Ediciones de la Universidad de Castilla-La Mancha.

Urdiales, A. (2008). La imagen exiliada. En Pelegrín, A., Sotomayor Sáez, M.V., \&t Urdiales, A. (eds.). Pequeña memoria recobrada: libros infantiles del exilio del 39 (pp. 57-79.). Madrid: Ministerio de Educación Cultura y Deporte. 